て貝にに台こい始のにものな的もし るはとた師よたて。いで蛀蛀尿云蛀 自己いのうい後そてあ六にを八六 屈行と。見な何のし六る即つ常し即 心人智解問を五て即と説い食の説 とを顗を題観即蛣をいはてと創は 上しがもに体行䖾詳え智もす見天 慢て天聊着と位六述る顗六ると台 心台 か眼しを即しが符即昆し六 を智 援して経と、湛を虫て即 除・教引て蛣るは且彼然説の有思 去信のし知蛀と理つは以く名想 さ行て礼六い即二何来べ種でに せを位蛣の即う蛣見故のきであお る具論蛀六を意蛀奇六六である。け た足で六即説味と異即即ある。る めしあ即観いないな議るが蛣四 で、る説をたのう蛣重のと、蛀明 あ修六の考のか小蛀重深主知 行即本察か。虫六視旨張礼は礼 た過を義じ。更か即学しは動无 天程創を盟本に稿知修説登たこ物旮 正おし らつ王礼行い訬し知ょ死 四いたか天ははした鈔た礼う体

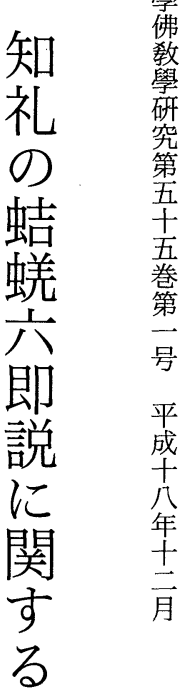

は彼六四る。述紫究と惹時る絫法過六 指天の智ら学要こ起疑にの层 要台旨罣礼机者がろし義宋学々天。 鈔宗を五はて誰あでた罆代者な正中

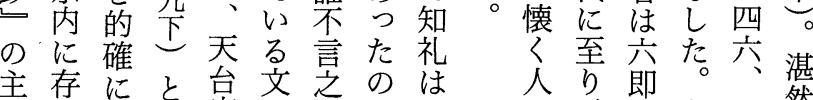

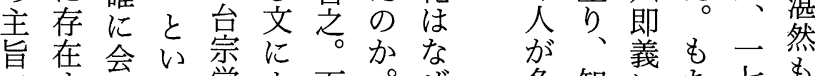
で考得う学上而。ぜ多知にち七も

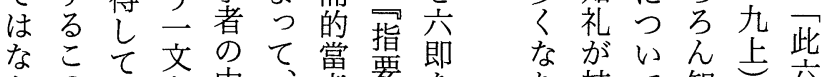
かのいを中て、當要即蛙て知已六 つ問る言でそ無鈔重、蛀異礼と即 た題人方事幾に視つ宍議が述義 のをはな理背地い即を蛣心゙起 で指実い同景天然そ蛙を説持蝰六自

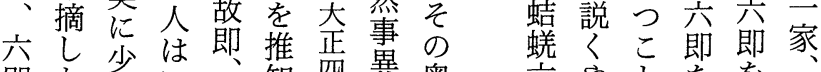

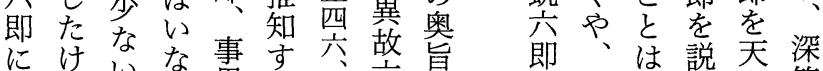

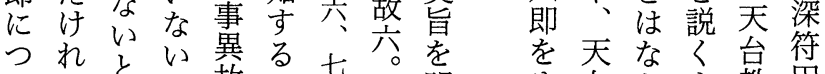
いどとが故こ吉理明め台かま教円 て 摘、六々八理らぐ宗っで学旨

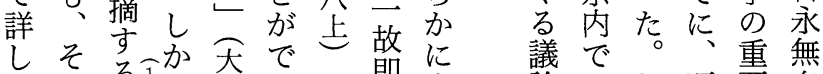

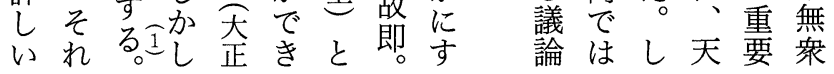

張 成 林 
十行を字不主し 法仏七亦界六義六即し六即説 界位経去唯張で、に界二同皆即即義知、即を明 知もとる顕しはそ渉よす彰理弁不にを礼天の格を 礼斉し時と佛た、のっりつ性其専つよは台旨別施 のして、は、の知例て乃至故初在いり 正をにし 蛣々顕仏名九礼飞理至上於、後佛て二妙統明重て 蛢名れ界字亦。はし即極と果無。知層宗のら視い 宍字るの以同蛣なて劣述成韭所一礼奛鈔六かしな 即ととみ後彰蛀ぜ蛣至の心゙法謂切はら即に詳か 説しいなの亲蛣蛀夌蛣、十界理仮加加義す述っ

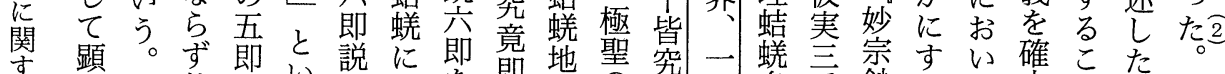
す顕。ず例他のい説に即竟地聖究二蛀竞宗すい確こた

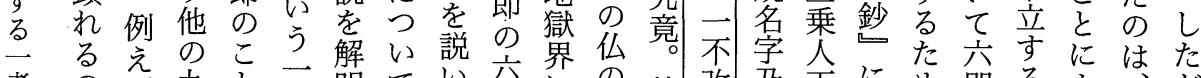
考のば九と文明てい六にの故改乃天にめ即るなはだ 察で行界で文卞もた即至及蛣。至、摚に仏たつ未が

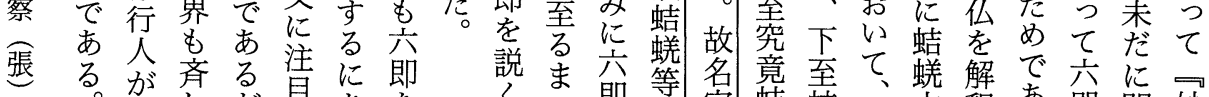

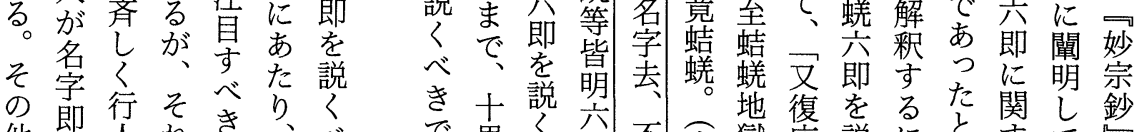

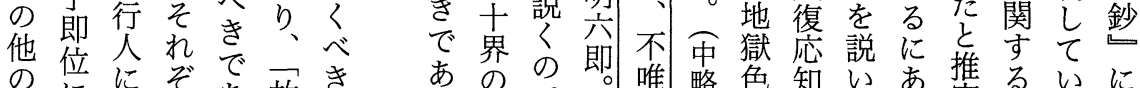

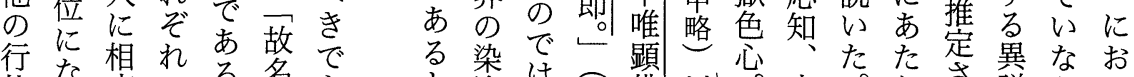

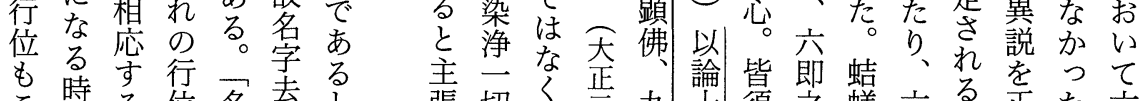
こ時る位名去る 辛切く焉九諭媲即蛙六る。正たて

これもでなあ故六が蛣そでつ一ら意蛣行いうれ とは十あらり、即極蛀のあま切な修味蛀位う。と を十界るぬ、無を聖を行るり法打行でにに。、同 明界はかこし非説の々位と天悉ししのつ相従究様 ら互斉らとか法く仏のをし台用摩始蛣い応っ竟で 加しこをも界べと例判、円六摩め蛀てして即あ にの々そ明十一き極外ず円教即訶て交もて功位る し天行十か界一で劣とる意の判歨後即六論故に。 、台人界すの不あのすこに立位觀ので即ず蛣なだ と法のにと二不る蛣るとょ場。に吾あをる蛀るか り界六わこ名改々蛀はがれかっに即っ説蛣等時ら わ観即たるは主。ずでばら奈は行てく蛀皆、

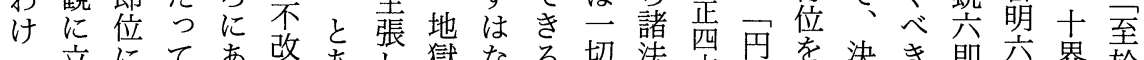
立にて古改あし獄なる切法宍観経決き即六界於 故脚相六るにるたとい即としを権経しでで即も果

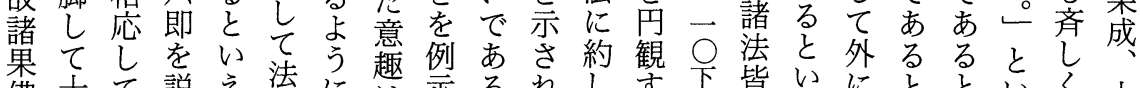

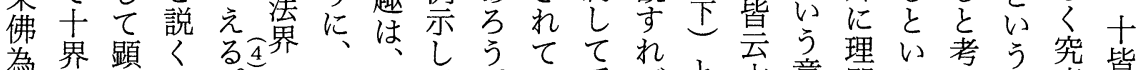
為界顕べ。亚十下、う、悉ば突意即う方の竟皆

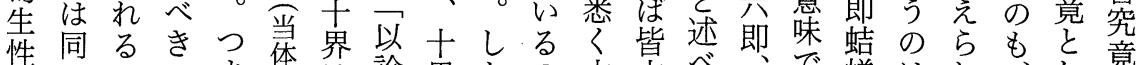
佛理のでま全は論界たの六公べ、で蛀はれ、即即ら故は竟

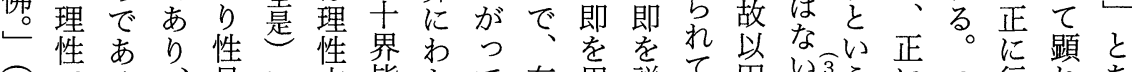
天でる、具に本皆たて有用説て用い令うにつ行秃あ 正古し十ほ具理っ知情いくい意虫こま人るる 晋るこか界かで性て礼のてのる。約かかのりのとょ 


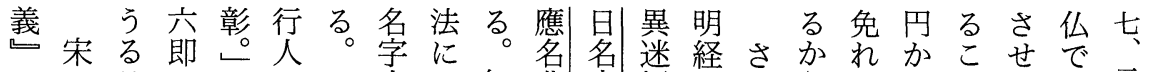
にの の お北を意い六こ界迷礼真十县句に可な十にのるる 礼

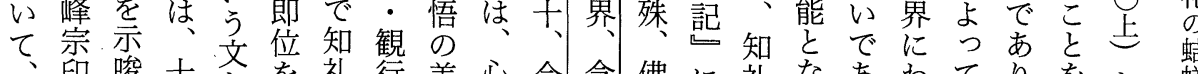

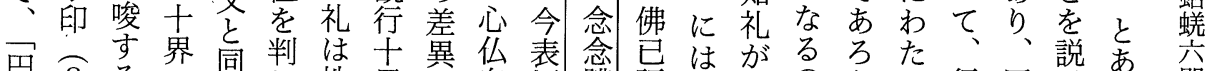

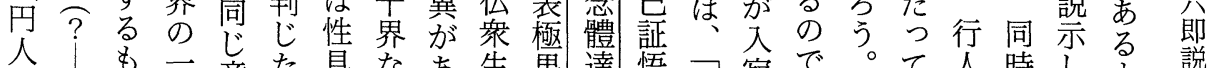
修二の切意た具なあ生果達悟口寂で。て人時しょ説 証三で法趣が界しるる㭆名㞣観法前る果即上性六に関 心三あに五この究し法䆓街在界前前仏を慢具即に守

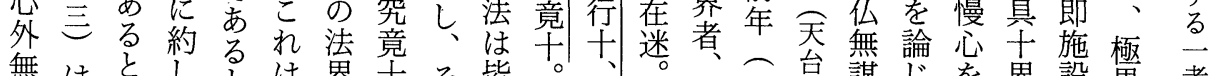

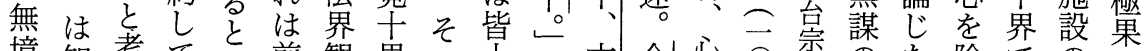

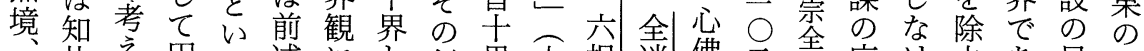

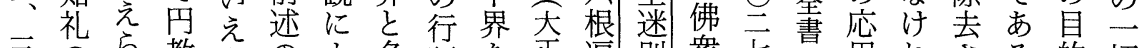
三のら教よのよ名証を正遍則衆志宣用れさる的切

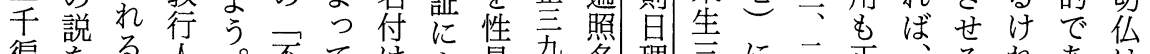

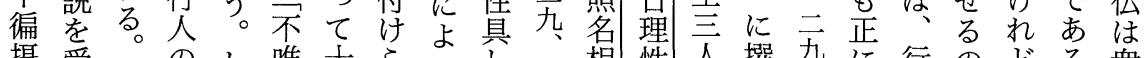
摂受 のし唯十らう界 一相性全撰芐に行のどる襌

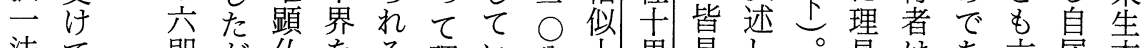
法て 即が仏をる理い八界具し。具はあ六屈本

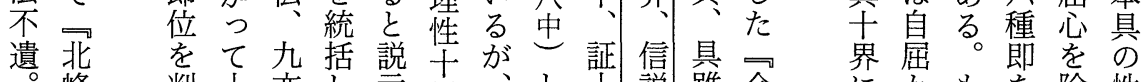

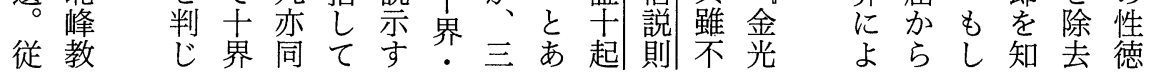

味蛏る虾で性方名は解るの釈人で場でず行乃略

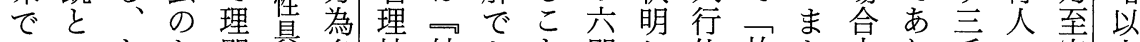
はいとた即其名蛣妙あと即し位故た市り手の究十 なういめ蛣界字䗘宗るに行、韭名慧界、の修竟界 い小うで蛀少蛙鈔とな位円唯字澄岁名法証則言 こ虫のな゙な名理䗘汝講思るは人去痴皆字を即遍論皆之

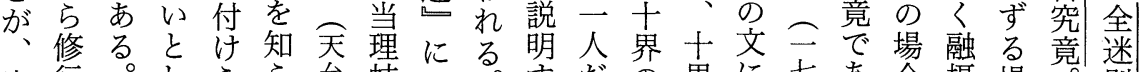

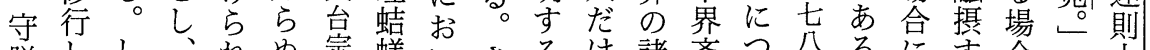

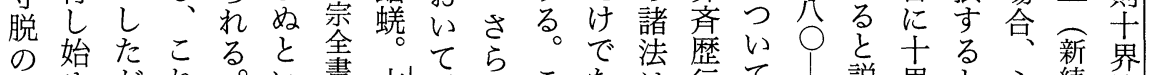
見めがれ。い書六、にこな行て、説界と心続皆

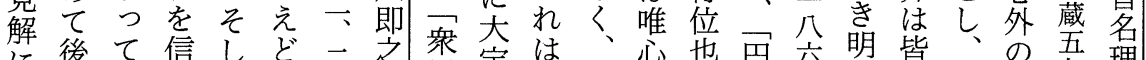

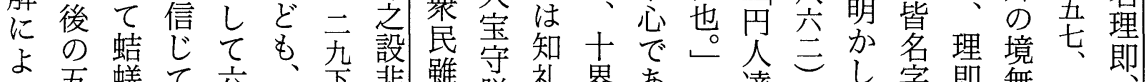

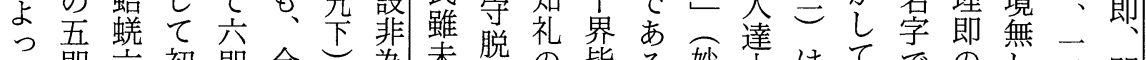

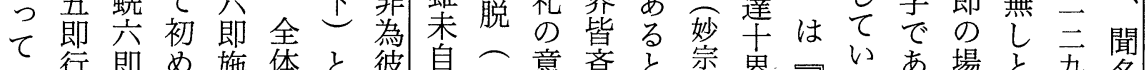

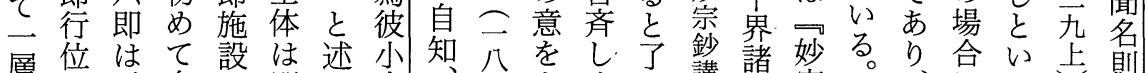

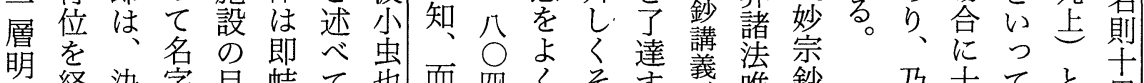
明経決字目蛣て也而四々之䢘義法鈔 加るし 即的蛀い全「味の机二心講 ととて蛙はでる。苟体元読行ば声無義

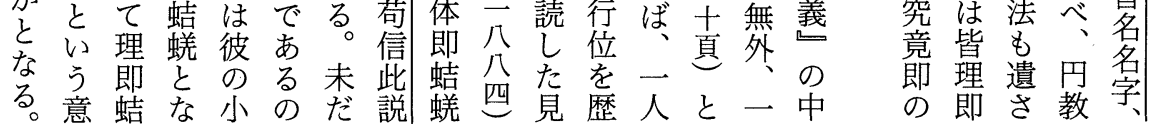


理ま説は界っかの観での約さ竟説の互に界し 性りい理にこら二体、唯しれ蛣叢かもも具行のか 知本行た性わの富心行心てて蛀書。こ十穴人二も 礼具人蛣本たよ究全人観蛣い者量宋万界ての切十 ので自蛙具つう竟真たがと蛀る界にので一い六法界 蛣盯六でてに蛣性場己は六。約は扶知々る即のは 蛀るの即あ六知蛀に合心、即こ正宗礼のが位中斉 六が唯はる即礼者にのを諸をの人集継は当故をでし 即故心行こをが持唯諸法説記唯者忠い体に判何々 説に観人を説 $\Rightarrow$ 約い心法皆い述心昌 20 全じれ行 関、体自をく妙、て観の総たに観只?た皆体うの人

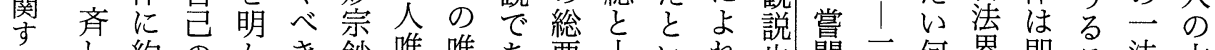
るし約のかき鈔唯唯あ要十い彵聞

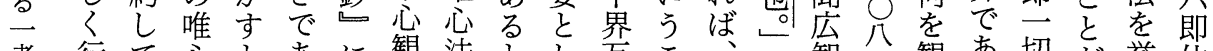
考 行て心とあに観法とし互こ界智刍観あ切が挙位 察人六観こる扔説界思具々知新旲已体る法知げに

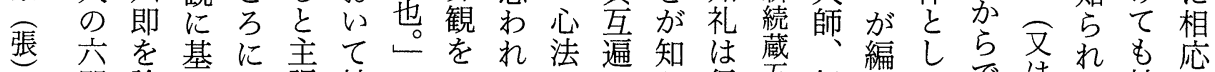

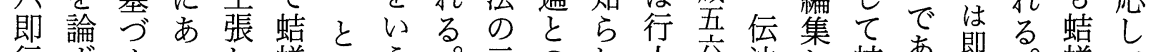
行ずくつし蛀いう。言のれ人六法し 蛣市即る。蛀て 位るもたた六うのつ平理る自八智た蛀る。法そ六顕 に場の。意即のでまをを。穴大六六的即れ 相合でそ趣をではり観領たの兰師四即ではとる

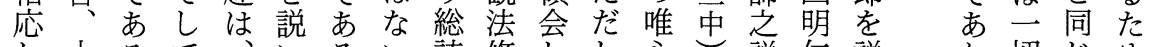
て十るて界。彼十て い。該修しし心説仁説り切じめ

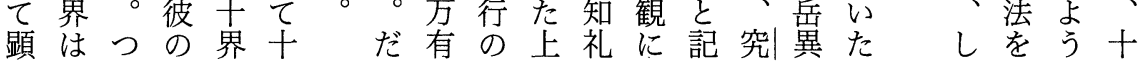

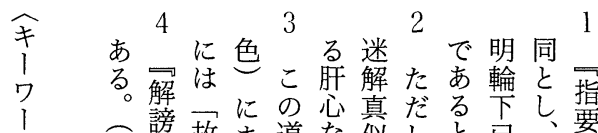

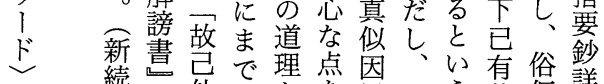

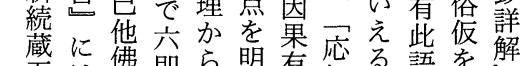

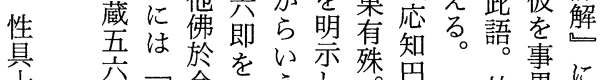

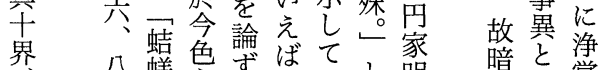

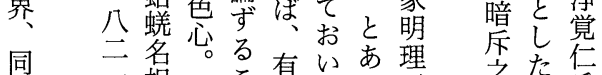

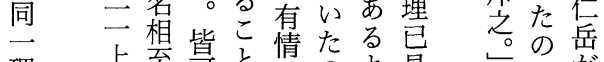

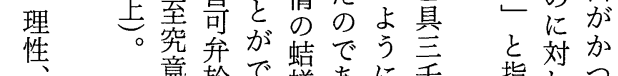

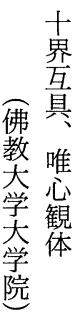

竟於で蛀古保平。 者宍き蝴る 此即る み。知而 此義とな礼皆

明也い号㞣性

性に学ず六不

具学方界即恋

界る。娶無旨約

也怒情理事

と鈔の 解乃 も雑 し
て六上れ唆もれ 後即慢ばす蛣る の説心行る蛀と 五はを者も六い 即除はの即う 行決去自も杗そ をてき心あじれ 経外なをるよは るにい免。う十 と理加円に界 い即 $ら$ 得か行 うのでずに人一 意蛣あ、十の切

味蛀乃同界六法 でとう時に即の はい。にわ行中 なうし六た位で い小た種っを何 こ虫が即て判れ がかつを六じの る義分 の 在 割 そ編 て の以中 一在を 例四理
判 5 知 即 う一

判修知らをる法 さ行礼な論こを さしのけじと挙 れ始蛣れなをげ るめ蜕ばけ示て 
search for Zhiyi's mind, and live within that mind. This is because Zhiyi lived according to his teaching and expressed his teaching through his lifestyle. Unless we too live within our teachings and express it through how we live, we will not be able to realize the Doctrine of Tiantai. It is my conviction that Tiantai Doctrine is a way of Buddhism that requires proving through the path we walk in life.

\section{Zhili's Theory of Jieqiang Liuji}

\section{ZHANG Cheng-lin}

Siming Zhili (四明知礼) maintained that the six stages of non-duality practices (六即Liuji) established in the Tiantai (天台) also applied to insects (蛣繒Jieqiang). But he intended to clarify that the ten realms (十界) are included in the intrinsic nature. He also explained that Jieqiang Liuji (蛣螧六即) based on the theory of one's own mind. Also the ten realms (十界) reveal themselves as the same rank with which a practitioner passes through the ranks of Liuji (六即). This is why the Jieqiang Liuji (蛣蛀六即) was explained. Therefore, his theory of Jieqiang Liuji (蛣䖾六即) does not mean that an insect called Liji Jieqiang理即蛣蜕 (the first stage of the Liuji六即) begins to practice, and then passes through the five ranks of the liuji (六即).

\section{The Buddhism of Tang Chang'an and Tiantai}

SUZUKI Gyōken

This study aims to clarify Tiantai in relation to the Buddhism of Tang period Chang'an. The position of Zhanran is not clear in the Song Gaosengzhuan or the funeral inscription of Zuoxi (故左溪大師碑). In addition, many Tiantai teachers are related to the Buddhism of Chanjan. This led to the loos formulation of a Tiantai lineage originally.

\section{A Few Problems of Zhiyi and Guanding}

\section{CHŌDŌ Kōshi}

Guanding 灌頂 made a written record and subsequently compiled the lectures of Zhiyi 智顗 as the three great Tiantai 天台三大部 commentaries. 